\title{
GREEN CAMPUS INITIATIVE: TRANSFORMING LAW IN BOOK INTO LAW IN ACTION*
}

\author{
Rina Shahriyani Shahrullah, ${ }^{* *}$ Agustina Fitrianingrum, ${ }^{* * *}$ \\ and R.A. Widyanti Diah Lestari ${ }^{* * * *}$ \\ Enviomental Law Deparment, Faculty of Law Universitas Internasional Batam, Batam \\ Gajah Mada Street, Baloi - Sei Ladi, Batam 29442
}

\begin{abstract}
Global warming has become a serious threat to our earth today. To overcome the problems of global warming, various parties should get involved including campus community (students, staff and faculty members). The participation of tertiary education institutions in minimizing global warming is referred to as 'green campus initiative'(GCI). This participation is mandated by Law No.32 of 2009 on Environmental Protection and Management. This paper suggests the adoption of GCI and provides a GCI model for Indonesian higher education institutions. This paper also discusses the GCI activities which can be adopted either by small or big campuses in Indonesia.
\end{abstract}

Keywords: green campus initiative, Batam.

\section{Intisari}

Pemanasan global telah menjadi ancaman serius bagi bumi kita dewasa ini. Untuk mengatasi masalah pemanasan global, berbagai pihak telah terlibat termasuk komunitas kampus (mahasiswa, karyawan dan dosen). Partisipasi perguruan tinggi dalam meminimalkan pemanasan global dinamakan 'green campus initiative (GCI)'. Partisipasi ini diamanatkan oleh Undang-Undang Nomor 32 Tahun 2009 tentang Perlindungan dan Pengelolaan Lingkungan Hidup. Makalah ini menyarankan penerapan GCI dan memberikan Model GCI untuk perguruan tinggi di Indonesia. Makalah ini juga membahas kegiatan-kegiatan GCI yang dapat digunakan baik oleh kampus kecil maupun besar di Indonesia.

Kata Kunci: green campus initiative, pemanasan global, Batam.

\section{Pokok Muatan}

A. Introduction 113

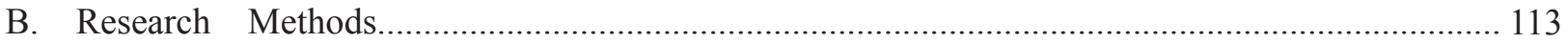

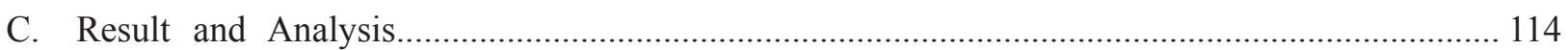

1. International and National Legal Framework on Environmental Management.......................... 114

2. Green Campus Initiative as An Environmentally Sustainable Strategy..................................... 115

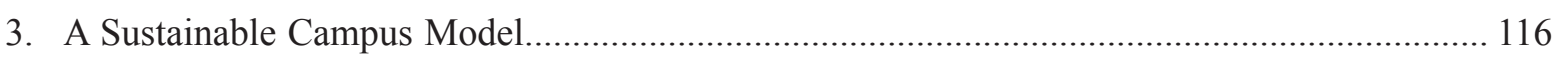

4. Green Campus Initiative Model of Harvard University......................................................... 117

5. Green Campus Framework by Dr. Arif Zulkifli Nasution....................................................... 118

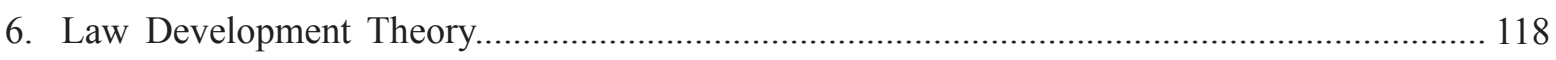

7. Concrete Actions of Higher Education Institutions in Implementing the Law Relating to

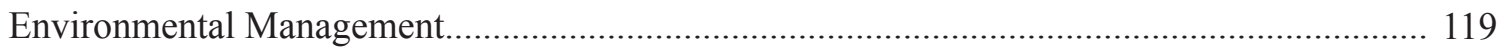

8. Green Campus Initiative (GCI) Model for Indonesian Higher Education Institutions............. 120

9. Green Campus Initiative (GCI) Activities for Small Campuses.............................................. 122

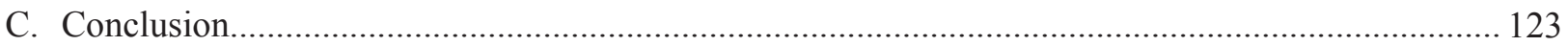

\footnotetext{
The research is funded by DIKTI under Hibah Bersaing Scheme 2012-2013.

** Correspondence address: rina@uib.ac.id

*** Correspondence address: agustina@uib.ac.id

**** Correspondence address: widyanti@uib.ac.id
} 


\section{A. Background}

Global warming is one of the gravest threats to the global environment and it has caused serious environmental and human health impacts today. ${ }^{1}$ Global warming occurs due to human activities which produce greenhouse gases (GHGs). ${ }^{2}$ Scientific evidence shows that global warming has already caused the average global sea level to rise between four and eight inches during the last 100 years. The seas are now rising at one tenth of an inch per year. ${ }^{3}$

Global warming has also greatly impacted on people in Batam. It was reported that on 13 January 2009, people in Batam suffered from severe flood caused by high tide which hit Tanjung Uma and Batu Besar. The flood destroyed a lot of fishermen houses and boats. ${ }^{4}$ Today, the climate in Batam is unpredictable and it gets hotter and hotter every day. This condition is also an impact of global warming. To overcome the problems of global warming, various parties should get involved. Government, private sector, civil society, education institutions, individual and other stakeholders should take part in reducing global warming by conducting pro-environmental activities. The participation of education institutions, particularly tertiary education institutions in minimizing global warming at campuses is referred to as 'green campus initiative' (hereafter refer to as GCI).

In Indonesia, GCI has been implemented by Universitas Indonesia (UI) since 2008. UI built a bicycle track around the campus for the purpose of limiting the use of motorbikes, so that the fuel emission which causes global warming may be reduced. ${ }^{5}$ This notion may not be suitable for all campuses in Indonesia, particularly campuses in Batam since all of campuses in Batam are very much smaller than the UI campus. Yet, it does not mean that small campuses in Batam cannot participate in minimizing global warming. This paper is to elaborate in a great detail how small campuses such as those in Batam can get involved in the GCI movement.

In general, this paper aims to discuss the concrete roles and participations of academic community in minimizing global warming in Batam. In order to achieve these main objectives, this paper contains more specific objectives as follows: Firstly, to discuss the concrete actions of higher education institutions in implementing the law relating to environmental management; Secondly, to provide a model of Green Campus Initiative (GCI) which is applicable for all campuses in Indonesia regardless their size; and Thirdly, to propose more suitable GCI activities for small campuses in Indonesia.

\section{B. Research Methods}

This research uses a socio-legal research method. A socio-legal research method requires the use of primary data which may be collected through observations, interviews, questionnaires or focus group discussions. ${ }^{6}$ The primary data for this research was collected through an observation at Universitas Indonesia (UI), Universitas Internasional Batam (UIB), Universitas Batam (UNIBA), Universitas Riau Kepulauan (UNRIKA), Universitas Putera Batam (UPB) and Universitas Ibnu Sina. In addition, interviews were also conducted at Universitas Indonesia (UI) in Jakarta and Universitas Internasional Batam (UIB) in Batam. Secondary data is also required by the socio-legal method to supplement the primary data. The secondary data used by this research is comprised of primary and

\footnotetext{
John Houghton, "Global Warming”, Report on Progress in Physics, Vol. 68, No. 6, June 2005, p. 1343-1403.

The United Nations Framework Convention on Climate Change defines greenhouse gases as "Those gaseous constituents of the atmosphere, both natural and anthropogenic, that absorb and re-emit infrared radiation," including $\mathrm{CO} 2$, methane, and nitrous oxide. United Nations Framework Convention on Climate Change, May 9, 1992, S TREATY DOC. NO. 102-38, 1771 U.N.T.S. 107, 31 I.L.M. 849 (1992) (entered into force as law in March 1994).

Bradford C. Mank, ’Standing And Global Warming: Is Injury To All Injury To None?”, Environmental Law Journal, Vol. 35, No. 1, 2005.

Muhammad Riza Fahlevi, "Efek Global Warming Hajar Batam”, http://rizafahlevi.blogspot.com/2009/01/efek-global-warming-hajar-batam. html, accessed on 22 April 2009

Universitas Indonesia, "Mark of Achievement of Universitas Indonesia”, http://www.ui.ac.id/en/profile/page/mark-of-achievement, accessed on 22 April 2009.

6 Amiruddin dan Zainal Asikin, 2004, Pengantar Metode Penelitian Hukum, RajaGrafindo Persada, Jakarta. See also Wignjosoebroto, 2002, Pengantar Metode Penelitian Hukum, RajaGrafindo Persada, Jakarta.
} 
secondary legal materials. The primary legal materials are comprised of Law No. 32 of 2009 on Environmental Protection and Management. The secondary legal materials are collected from articles, books, and other materials relevant to global warming and environmental management. All data collected in this research was analysed based on its content (a content analysis) by using the qualitative approach. In order to accurately interpret the data, the qualitative approach utilizes the text and systematic interpretation. ${ }^{7}$

\section{Result and Analysis}

\section{International and National Legal Frame-} work on Environmental Management

At international level, the United Nations authorized an Intergovernmental Negotiating Committee on Climate in 1990 in response to the concerns of global community to the impacts of global warming and climate change. The United Nations Framework Convention on Climate Change (UNFCCC) provides the guiding principles and negotiating platform for multilateral actions to address human-induced climate change. The UNFCCC took effect in 1994 and it was ratified by 192 states, including the United States by 2007.

Since the process of human-induced climate change was accelerating during the early-to-mid 1990 s, the international community negotiated a new agreement during 1995-1997 (under the UNFCCC) to curb the growth in greenhouse gas emissions. The main elements of the negotiation lead to the establishment of the Kyoto Protocol. The Kyoto Protocol was agreed in late 1997 and it was entered into force on 16 February 2005. As of early 2008, the Protocol was ratified by at least 175 states, excluding the United States.

Indonesia signed the UNFCCC on 5 June 1992 and ratified the Convention by Law No. 6 of 1994. The Convention was entered into force in Indonesia on 21 November 1994. Indonesia has also ratified the Kyoto Protocol by Law No. 17 of 2004. As a ratifying state to the United Nations Framework Convention on Climate Change and the Kyoto Protocol, the Indonesian government has been actively involving in overcoming the problem of climate change. To strengthen the position of Indonesia in international forums in controlling climate change, the Government of Indonesia established the National Council Climate Change (DNPI) through the Presidential Regulation of the Republic of Indonesia Number 46 of 2008.

At national level, Indonesia has a law pursuant to protection and environmental management, namely Law No. 32 of 2009 on Environmental Protection and Management. Article 1(1) of Law No. 32 of 2009 defines that:

Environment shall be a totality of space with all materials, resources, situations and creatures, including human and theirs behaviour that influence the nature, continuation of livelihood and human welfare as well as other creatures.

Even though the term 'environment' in ecological meaning does not adopt a territorial or administrative limitation, an environmental management should clearly define its territorial management. ${ }^{8}$ Hence, the environmental management discussed by this paper is limited to the territory of Indonesia, particularly Batam. Environmental protection and management can be defined as 'be systematic and integrated efforts to preserve the functions of the environment and prevent environmental pollution and/or destruction, which cover planning, utilization, control, preservation, supervision and law enforcement'. ${ }^{9}$ Article 3 of Law No.32 of 2009 further states that:

Environmental Protection and Management shall aim: (a) protecting the territory of the Unitary State of the Republic of Indonesia from environmental pollution and/or damage; (b) assuring human safety, health and life; (c) assuring the continuation of life of creatures

\footnotetext{
Sudikno Mertokusumo, 1986, Mengenal Hukum (Suatu Pengantar), Liberty, Yogyakarta.

Rahmadi Usman, 2003, Pembaharuan Hukum Lingkungan Nasional, Citra Aditya Bakti, Bandung.

Article 1(2) of Law Number 32 of 2009 on Environmental Protection and Management (State Gazette of the Republic of Indonesia Year 2009 No. 140, Supplement to State Gazette of the Republic of Indonesia No. 5009).
} 
and ecosystem conservation; (d) preserving the conservation of environmental functions; (e) achieving environmental harmony, synchronization and balance; (f) assuring the fulfilment of justice for the present and future generations; (g) assuring the fulfilment and protection of right to the environment as part of human rights; (h) controlling the utilization of natural resources wisely; i.e. realizing sustainable development; and (j) anticipating global environmental issues.

In relation to the implementation of protection and environmental management in Indonesia, Article 65(4) of Law No.32 of 2009 stipulates that "Everybody shall reserve a right to participate in the environmental protection and management in accordance with legislation'. In addition to the rights to participate in environmental management, 'everybody shall be obliged to preserve the environmental functions as well as control environmental pollution and/or damage". ${ }^{10}$

\section{Green Campus Initiative as An Environ- mentally Sustainable Strategy}

The term 'Green Campus Initiative' has been popularized by Harvard University since 2000. This university is also considered as the best example in implementing 'Green Campus Initiative'. The pur- poses of the Harvard GCI are as follows: ${ }^{11}$

a. Creating and maintaining an enormous web of relationship across Harvard, actively engaging and coordinating a critical mass of people in conversations and partnerships that continue to lead to new ideas, new priorities and new kinds of engagement.

b. Providing the human resources, expertise, business models, education, training, financial incentives and case studies to overcome all existing barriers to wide scale operational change.

c. Implementing hundreds of successful green campus projects each year, building the confidence and commitment of hundreds of campus operations staff as well as fostering new attitudes and behaviours in thousands of students, staff and faculty alike.

d. Ensuring continuous improvement by encouraging Harvard to continue on its journey towards innovation and systemic transformation.

Harvard University conducts the GCI monthly activities which involve all internal stakeholders of the university. The following table is an example of the Harvard GCI monthly activities. ${ }^{12}$

Table 1. The Harvard GCI Monthly Activity

\begin{tabular}{ll}
\hline Month & \multicolumn{1}{c}{ Theme } \\
\hline January & Turn off light and use CLF's \\
February & Put computers to sleep and turn them off \\
March & Use and turn off power strip/unplug old changers \\
April & Celebration of Earth Day/Recognition \\
May & Wash clothes in cold water \\
June & Drive less \\
July & Eat less meat and go local \\
August & Reduce, Reuse, Recycle \\
September & Take shorter showers/tunr off tap \\
October & Celebration of Sustainability/Recognition \\
November & Ditch plastic \\
December & Adjust your thermostat \\
\hline
\end{tabular}

Source: Sustainability at Harvard, 2009.

\footnotetext{
10 Article 67 of Law Number 32 of 2009 on Environmental Protection and Management (State Gazette of the Republic of Indonesia Year 2009 No. 140, Supplement to State Gazette of the Republic of Indonesia No. 5009).

11 Anonymous, “HGCI Growing, Growing, Grown!”, Harvard Green Campus Initiative Newsletter 07, Spring, Vol. 10, 2007, p. 2.

12 Harvard University, "Sustainability at Harvard", http://green.harvard.edu/, accessed on 22 April 2009.
} 
The term 'Green Campus Initiative (GCI)' may not be so popular among higher education institutions in Indonesia. Up to now, only Universitas Indonesia (UI) adopts the term. Yet, it does not imply that pro-environmental activities have not been carried out by other higher education institutions in Indonesia. Nevertheless, there is a distinction between GCI and other pro-environmental activities. GCI is a systematic, integrated and sustainable proenvironmental program, whereas pro-environmental activities are usually conducted irregularly.

$\mathrm{UI}$ is one of the higher education institutions adopting the GCI to minimize global warming. One of the UIB Website ${ }^{13}$ states that:

Global warming is a reflection of the unsynchronized development of science and technology with the human awareness of the environment on moral and ethical level. In order to anticipate this, Universitas Indonesia has an obsession to create an environmentbased campus or known as the "green campus".

The official website of UI reports one of its achievements, namely: ${ }^{14}$

Through a green campus initiative, more than 40.000 members of the Universitas Indonesia community to support, promote and ensure sustainable future in which the global warming are the main concern. Ten kilometres of bicycle track has been built across Universitas Indonesia Depok Campus during 2008.

In addition to a bicycle track, UI has also developed four ecosystem components in University of Indonesia, lies in Depok. They are the physical building and green landscape buffer of 170 ha, water ecosystem of 30 ha, city forest area of 100 ha, and supporting facilities and infrastructure, including environment buffer of 12 ha. City forest, managed by University of Indonesia, has tropical rainforest characteristics with three types of advanced ecosystem, namely: 'tree ecosystem from eastern part of Indonesia, tree ecosystem from western part of Indonesia and JABODETABEK original vegetation complex combined with Jati Mas Forest growing green Rector Building and Faculty of Computer Science and Faculty of Social and Political Science Building'. ${ }^{15}$

\section{A Sustainable Campus Model}

In December 2002, the United Nations Resolution 57/254 was adopted which established the United Nations Decade of Education for Sustainable Development (2005-2014). Today, various higher education institutions have adopted the movement toward sustainability or green campus. A successful endeavor to green campus involves internal and external stakeholders of higher education institutions. They are the administration, academic departments (students and faculty), the university research and the local community. ${ }^{16}$ The administration, academic departments (students and faculty) and university research can be referred to as 'internal stakeholders', and the local community can be referred to as 'external stakeholder' of higher education institution. The following explanations are to describe the roles and functions of internal and external stakeholders of higher education institutions. ${ }^{17}$

\section{a) Administration (Government)}

The administration has a very significant impact by the business decisions they make concerning new building design, repair and renovation projects, building operations and maintenance, procurement practices, landscaping, recycling at various levels, waste management, custodial services, energy management, transportation, food service and dining operations, and residential operations.

\section{b) Academic Departments}

The educational side is also significant but in different ways. The investment in the education of students on these

\footnotetext{
Website Universitas Indonesia, "Green Campus", http://www.ui.ac.id/en/campus/page/green-campus, accessed on 22 April 2009.

Mark of Achievement of Universitas Indonesia, Loc.cit.

Green Campus, Loc.cit.

Anonymous, "The Sustainable Campus", http://www.sustainablecampus.org/universities.html, accessed on 22 April 2009

The Sustainable Campus, Loc.cit.
} 
subjects has a long term benefit. They will eventually become leaders in their community and bring with them the important concepts of sustainability. Service-learning is an important teaching method that allows students to learn required curriculum while applying what they learn to real world problems. This learning model is very well suited to the university environment and is a way to integrate knowledge base with local requirements and applications. This can have an immediate benefit depending on the nature of the service requirement. Further educational opportunities exist with developing courses on sustainable development, informal workshops and training, as well as distance learning'.

c) Research

The research sector of the university has a significant role in terms of its near and long term impacts. There are already on-going projects with ecological habitats and other environmental issues. Areas for research could also include large scale composting, procurement practices, production methods, alternative energy sources, and any number of building design, construction, operations, and maintenance practices.

d) Local Community

The local community can also provide various levels of resources to assist the sustainability effort and includes alumni, the business community, util- ity suppliers, transportation providers, vendors, community organizations, and local chapters of professional associations.

The participation of internal and external stakeholders of higher education institutions toward sustainability or green campus is presented by the following model. ${ }^{18}$

\section{Figure 1. A Sustainable Campus Model}

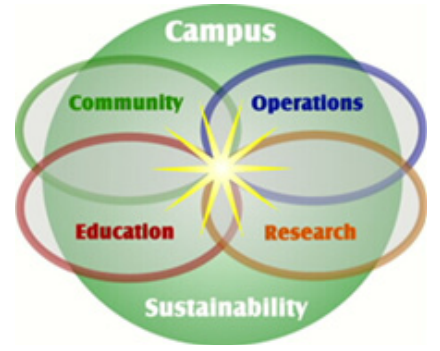

Source: Sustainability at Harvard, 2009

\section{Green Campus Initiative Model of Har-} vard University

The Harvard Green Campus Initiative is 'an interfaculty program that strives to achieve the environmental, human health and financial benefits of high performance campus planning, design and operations'. The Harvard GCI works to address the real life challenges of environmental sustainability by developing the capacities of staff, students and Faculty to address the demands of sustainability in a myriad of University contexts. ${ }^{19}$ The Harvard Green Campus covers various aspects which are best described by the following Harvard GCI Model. ${ }^{20}$

The Sustainable Campus, Loc.cit.

19 Harvard University, "Harvard Green Campus Initiative Newsletter", Spring, Vol. 5, 2004, p.1.

20 Leith Sharp, "Green Campuses: The Road From Little Victories To Systemic Transformation", International Journal of Sustainability in Higher Education, Vol. 3. No. 2002. 
Figure 2. The Harvard Green Campus Initiative Model

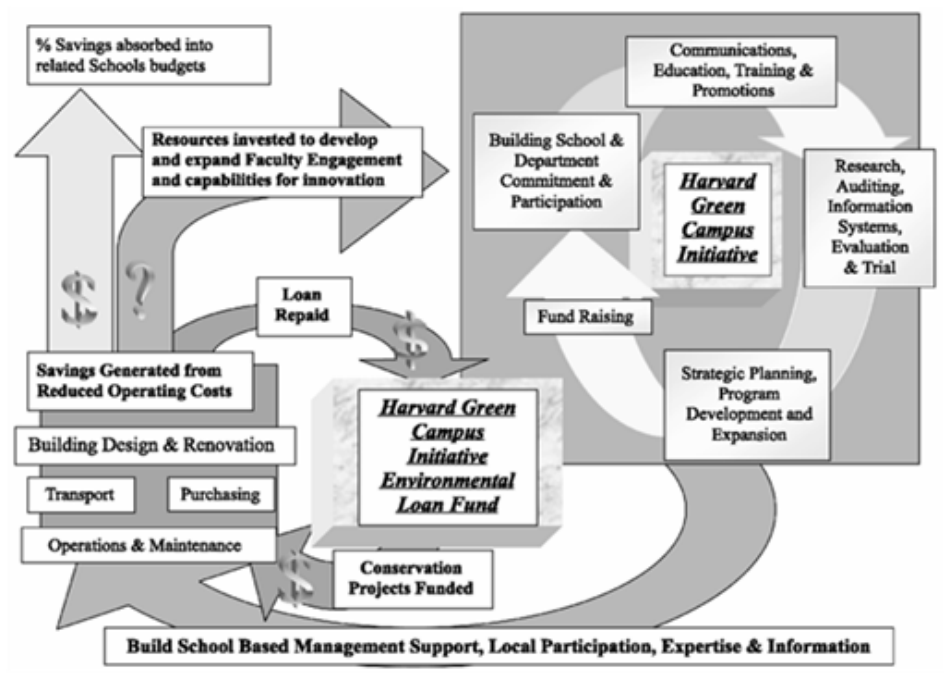

Source: Sustainability at Harvard, 2009.

5. Green Campus Framework by Dr. Arif Zulkifli Nasution

Dr. Arif Zulkifli Nasution is one of Indonesian environmentalists. According to him, the term 'green campus' is an educational system, research, community service and environmentally friendly location which involve campus community in environmental activities that have positive impacts on environment, economy and society. ${ }^{21}$ Dr. Nasution proposes a green campus framework as follows: ${ }^{22}$

Figure 3. Green Campus Framework

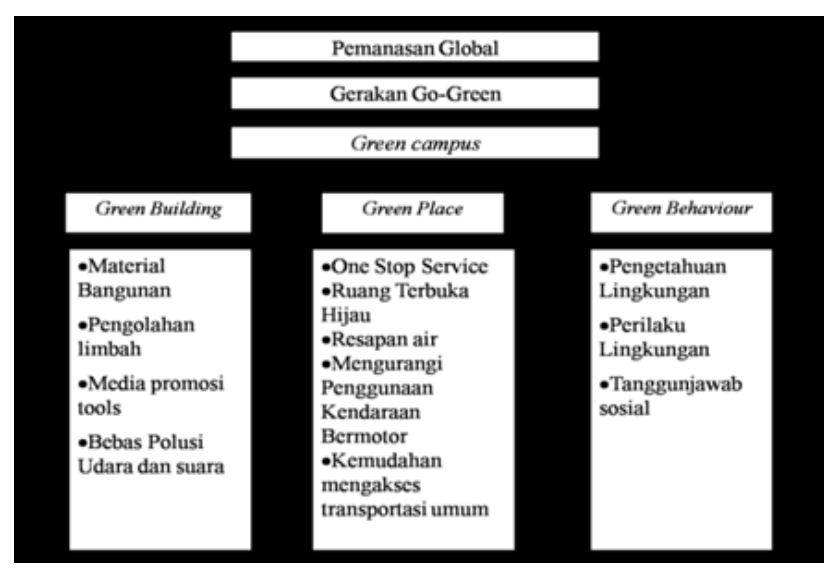

Source: Nasution, 2009.

The Green Campus Framework consists of three aspects, namely 'Green Building, Green Place and Green Behavior'. Green Building covers four aspects, namely 'environmentally friendly construction materials, waste management, environmentally promotion tools and free pollution'. Green Place is comprised of five aspects, namely 'one stop service, green open space, water absorb- ance, minimizing the use of motorbikes or cars, accessibility to public transports'. Green behavior consists of three characters, namely 'environmental knowledge, environmental attitudes, and social responsibility'. ${ }^{23}$

\section{Law Development Theory \\ Mochtar Kusumaatmadja developed a theory} of law for Indonesia. The theory is called 'Teori Hu-

\footnotetext{
${ }_{21}$ Arif Zulkifli Nasution, "Green Campus", http://bangazul.blogspot.com/2012/09/green-campus.html, accessed on 22 April 2009 
kum Pembangunan' (Law-Development Theory). This theory is derived from the theory of Roscoe Pound that points out the end of law as follows: ${ }^{24}$ It [the legal order] may well be thought of as a task or as a great series of tasks of social engineering; as an elimination of friction and precluding of waste, so far as possible, in the satisfaction of infinite human desires out of relatively finite store of the material goods of existence.

In the opinion of Roscoe Pound, 'law as a tool of social engineering is more concerned with actual operation of law rather than its abstract content. Accordingly, law emphasizes on its social purposes rather than sanction. ${ }^{25}$ Different from Roscoe Pound, Mochtar Kusumaatmadja was in the opinion that law should not be used as 'a tool', but it should be used as 'a means'. According to Mochtar Kusumaatmadja, 'law is a means to maintain order in society'. The role of law is 'to ensure the dynamic changes occur in regular manner'. Law is 'a society's renewal media which means that law should serve as a director for society's actions to support the development'. ${ }^{26}$

\section{Concrete Actions of Higher Education In- stitutions in Implementing the Law Relat- ing to Environmental Management}

Article 65(4) of Law No.32 of 2009 stipulates that 'Everybody shall reserve a right to participate in the environmental protection and management in accordance with legislation'. This provision clearly requires the participation of each individual to participate actively in the environmental management. This provision has been implemented by many higher education institutions in Indonesia. Hermawan ${ }^{27}$ in his research entitled 'The Role of Universities in Environmental Education in Indonesia', finds that several universities such as Universitas Gadjah Mada (UGM), Universitas Indonesia (UI), Institut Pertanian Bogor (IPB) dan Universitas Ne- geri Jakarta (UNJ) are the pioneers in conducting programs and activities on environment. UNJ for example has carried out a Postgraduate Program in Population and Environment. UGM and UNY have developed training programs, seminars and workshops on environmental education. ${ }^{28}$ In addition, UGM and UNY have selected a number of elementary schools as their target groups in developing environmental education at primary school level. In performing this particular educational approach, the universities integrate the environmental education into the relevant subjects or extra-curricular activities at elementary schools. ${ }^{29}$ Other universities which are also active in environmental activities are Universitas Nasional (UNAS), Institut Pertanian Bogor (IPB), Universitas Parahiyangan (UNPAR) and Universitas Kristen Satya Wacana (UKSW) ${ }^{30}$

In addition to higher education institutions in Java Island, environmental activities have also been carried out by higher education institutions in Riau Islands Province (Propinsi Kepulauan Riau/ KEPRI). Yet, the main distinction between the educational institutions in Java and KEPRI is that the size of the institutions in KEPRI is much smaller than those in Java. Universitas Internasional Batam (UIB) in KEPRI conducts environmental activities through a student organization called 'UIB Social Activities (USA)'.

USA is a means not only for students but also all UIB community members to continuously participate in performing good deeds to all humans including animals, plants and environment. This notion aligns with the USA vision, that is 'USA is a means for the UIB community to continuously involve in social and humanitarian activities in order to cultivate the sense of empathy and caring in their life'. Environmental activities which have been conducted by USA are 'tree planting, eco-enzyme making, recycling, environmental campaigns, and

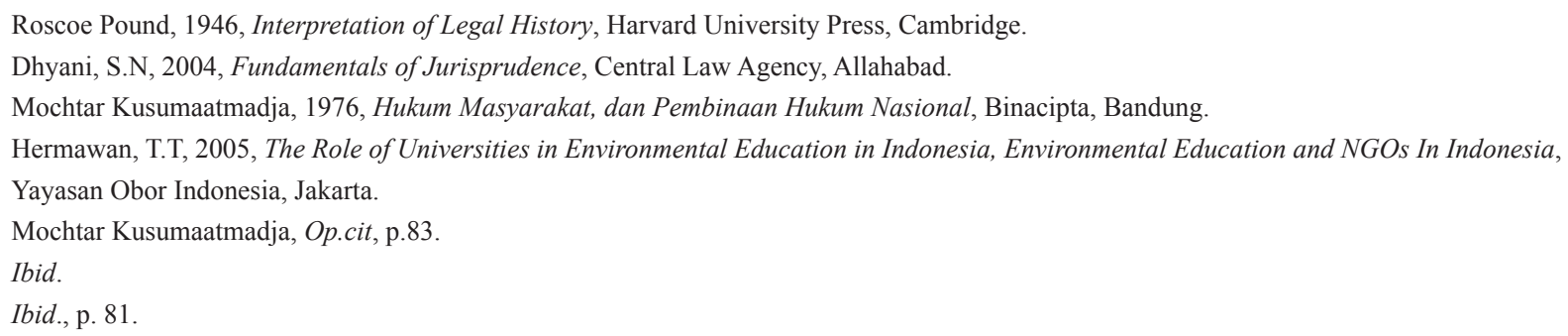


so forth. The activities are not only taken place regularly at the UIB campus, but they are also disseminated to public. This approach is adopted by the USA in order to achieve its mission: 1) to actively participate in social and humanitarian activities in and outside of the UIB campus; 2) to cultivate the sense of caring for others among the UIB community as the reflection of compassion and thankfulness; 3) to be pro-active in collaborating with communities and institutions in carrying out the UIB social responsibilities for the betterment of society.

Universitas Riau Kepulauan (UNRIKA) has implemented environmental values in all types of interactions in and outside campus by way of establishing 'the environmentally friendly campus movements'. The movements have implemented concrete actions through water management and energy saving in UNRIKA. In 2010, the Himpunan Mahasiswa Pencinta Alam (HIMPALA) UNRIKA initiated a campus forest (Arboterium). Several distinct trees were planted on the 0.5 acres around the UNRIKA campus for conservation and recreation. Another university in KEPRI which has also implemented environmental activities is Universitas Batam (UNIBA). This university planted trees around its campus.

The concrete actions of many higher education institutions in Indonesia indicate that Law No.32 of 2009 is not merely 'Law in Book', but it has been transformed to be 'Law in Action'. The environmental activities of universities in Java and outside Java (i.e. KEPRI) reflect a concretization of the Law-Development Theory of Mochtar Kusumaatmadja. In this regard, Law No.32 of 2009 is used as a means to support the development, particularly the environmental management.

\section{Green Campus Initiative (GCI) Model for Indonesian Higher Education Institutions}

The environmental activities have been carried out by many higher education institutions in Indonesia. Yet, it is quite unfortunate that the activi- ties are not fully integrated in the system of higher education institution in Indonesia. As the result, not all campus communities (i.e. students, staff and faculty members) get involved in the activities. Tree planting activity around campus may not be conducted every day because of the high cost and time consuming. Therefore, it is imperative to establish a model for environment which is integrated, systematic, sustainable and supported by a full participation of campus community. Green Campus Initiative (GCI) may be an appropriate model for environmental activities at campus. This is because GCI constitutes 'an interfaculty program that strives to achieve the environmental, human health and financial benefits of high performance campus planning, design and operations'. ${ }^{31}$

GCI is not so popular in Indonesia even though UI has adopted it to minimize global warming. Based on the author's observation and interviews at $\mathrm{UI}^{32}$, GCI is still not fully integrated by all types of learning process and interactions at UI. Hence, the author proposes a GCI Model which is considered suitable for all campuses in Indonesia. ${ }^{33}$ The process of designing the model is by using a comparative approach. In this conjunction, the Sustainable Campus Model, Harvard GCI Model and Green Campus Framework by Dr. Arif Zulkifli Nasution as elaborated in Part III of this paper are examined. Based on the analysis of the models, it is concluded that four significant points should exist in GCI, namely 'Policy, Infrastructure, Academic and Non Academic Program of Higher Education Institution'. As the result of the analysis, the proposed GCI model for Indonesia is as follows:

The GCI Model above consists of 5 (five) aspects, namely:

a) GCI Policy of Higher Education Institution

GCI should be fully supported by the authority of higher education institu-

\footnotetext{
Harvard Green Campus Initiative Newsletter, Op.cit, p. 1.

32 Observation and interview with Himpunan Mahasiswa Pencinta Alam UI at UI on 27 March 2012.

33 The model is designed based on the research funded by DIKTI under Hibah Bersaing Scheme 2012.
} 


\section{Figure 4. Green Campus Initiative Model}

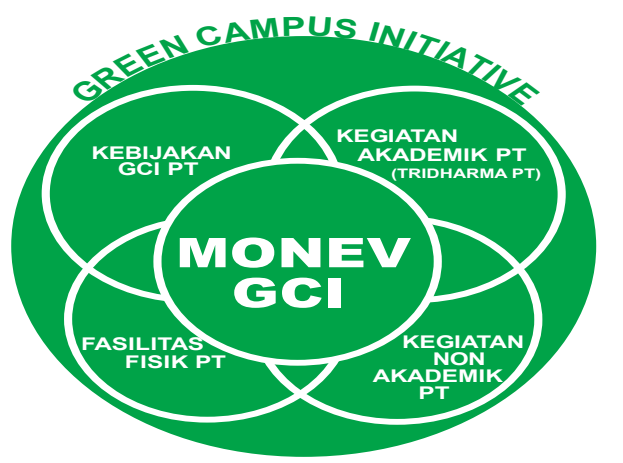

Source: Research Result, 2012.

tions for it to work effectively. In this regard, the GCI approaches and programs should be integrated in the official documents of higher education institutions such as Quality Policy ${ }^{34}$, Quality Objective ${ }^{35}$ and Strategic Plan (Rencana Strategi/Renstra). The integration of GCI into the official documents purports to bind all campus community officially and legally; consequently GCI is an imperative program in the entire system of higher education institution.

b) Academic Activities of Higher Education Institution

Since GCI is an integrated part of the system of higher education institution, the three pillars of academic activities, namely 'Education and Learning, Research, Community Service' should also integrate the GCI approaches. As the consequence, the process of learning should adopt the environmentally friendly approaches. For example: minimizing the use of paper in the learning process. Research should be dedicated for a better environment and humanity. Yet, it does not mean research is only limited to environmental issues. Any research can support a betterment of environment. Society service should be devoted for the improvement of environment and community.

c) Non Academic Activities of Higher Education Institution

Non-academic activities conducted in or outside campus should be 'environmentally-result oriented'. It means that the activities should aim to improve the quality of environment and minimize the exploitation of environment which leads to its destruction. Activities such as recycling, energy saving, and other pro-environmental activities should be prioritized by Higher Education Institutions when they perform their community services.

d) Infrastructure of Higher Education Institution

Infrastructure or facilities should be 'environmentally friendly'. Hence,

34 Quality Policy is an official statement given by top management regarding the objectives and directions of quality performance of organization. Quality policy should align with the organization purposes and the framework of organization. In order to ensure its affectivity, a quality policy should be: established officially; communicated and understood by all staff; well documented and controlled; reviewed regularly to ensure its alignment with the organization's vision, mission and strategic plans. See also Anonymous, "ISO 9001: Quality Policy atau Kebijakan Mutu", http://iso-9001-forum.blogspot.com/2009/02/iso-9001-quality-policy-atau-kebijakan.html, accessed on 22 April 2013.

35 Quality objectives are 'quality standards' which constitute the manifestation of the quality policy. The quality objectives should be 'strategic, specific, measurable, realistic and achievable in a certain prescribed period'. See also Website Universitas Islam Indonesia, "Perangkat Sistem Penjaminan Mutu UII Yogyakarta", http://ipan.staff.uii.ac.id/2009/02/perangkat-sistem-penjaminan-mutu-uii-yogyakarta/, accessed on 22 April 2013. 
building design, construction and maintenance practices should be proenvironment in the sense that all facilities must not destroy environment and/ or exploit it exaggeratedly.

e) GCI Monitoring and Evaluation (MONEV)

The four aspects mentioned above should be monitored and evaluated periodically in order to ascertain the effective implementation and achievement of GCI. The Monev is significantly required to guarantee a continuous improvement of GCI and to achieve the demands of sustainability in a myriad of Higher Education Institution contexts.

\section{Green Campus Initiative (GCI) Activities for Small Campuses}

Many higher education institutions in Indonesia have carried out various environmental activities in or outside their campus. However, environmental activities at one campus may be difficult to be adopted by another campus, simply because the condition of the campus is not suitable for such activities. For example, a bicycle track may also be suitable for a campus with large area. Similarly, not many campuses have big lands to establish a campus forest. In addition, building a bicycle track or establishing a campus forest is relatively expensive. However, such limitations should not impede the implementation of GCI since GCI may be imposed on all campuses regardless their size and condition. A number of GCI activities can be conducted by small campuses with a minimum cost or no cost at all. The following examples are the GCI activities which have been implemented by Universitas Internasional Batam (UIB) whose campus is considered smaller than the ones in Java. UIB has 5 acres land, but only $1 / 3$ of the land has been built to conduct a learning process. Yet, the activities below can be adopted by small or big campuses in or outside Batam.

a) Eco-Enzyme

Eco Enzyme is a complex organic sub- stance consisting of protein chains and mineral salt. The eco-enzyme can be used as natural pesticide, dish washing liquid, detergent, floor cleaning liquid, fruits and vegetables washing liquid. The making of eco-enzyme is very easy; therefore students, staff, faculty members of a higher education institution and community members may participate in the process of making the eco-enzyme. The materials for the eco-enzyme are: (1) organic waste (3 kg); (2) palm sugar (1 kg); (3) water (10 liter); (4) bucket with a lid. The ways of making the eco-enzyme: (1) the organic waste is mixed with palm sugar and water in the bucket; (2) let the mix to be fermented for 3 (three) months, yet the mix should be opened and stirred once a week to release gas in the bucket; (3) after 3 (three) months, filter the water and get rid of the organic waste; (4) put the eco-enzyme liquid in recycled bottles; (5) the eco-enzyme liquid is ready for use.

\section{b) Recycling}

Recycling is one of the GCI activities which can be done every day involving all campus community members. Recycling process does not incur any expenses; on the contrary recycling may bring additional revenue because the recycled goods can be sold. The method of recycling is very easy. Rubbish bins in campus should be classified into organic and non-organic waste. Non-organic waste may be further divided into plastics, paper and bottles. All campus community members should be discipline when throwing rubbish in the sense they have to throw their rubbish in the right bins. Recycling is much easier to do when all rubbish bins are already classified. The following photo shows the recycling activity at Universitas Internasional Batam in Riau Islands Province (KEPRI).

c) Environmental Campaigns and Practices

Other GCI activities which can be implemented by small campuses are envi- 
ronmental campaigns and practices. Campus community can participate to save energy by turning all lights, computers and $\mathrm{AC}$ off when they leave their rooms or class rooms. Paperless system may also be carried out by small campuses. In this regard, students, staff and faculty members are only allowed to use used paper. All students' assignments should not be printed on paper; they have to use a softcopy form instead. All campus community members should bring their own plastic bottle to campus in order to minimize the use of disposable plastic glasses. By conducting these campaigns and practices every day, 'pro-environment attitudes' may become an integrated behavior and attitude of all campus community. Such a good character may eventually form an environmental awareness culture of all campus community.

\section{Conclusion}

Article 67 of Law No.32 of 2009 clearly stipulates that 'everybody shall be obliged to preserve the environmental functions as well as control environmental pollution and/or damage'. This provision is commonly referred to as 'law in book' which is needed to be concretely implemented to be 'law in action'. Minimizing global warming through 'proenvironmental activities' is one of the concrete actions to transform 'the law in book' to be 'the law in action'. Campus community which is comprised of students, staff and faculty members (internal stakeholders) can take concrete actions in minimizing global warming by implementing 'Green Campus Initiative (GCI)' activities.

The successful of GCI activities depend on the full participation of all campus community members. Therefore, GCI should be integrated in the official documents of higher education institutions in order to obtain full supports from all campus community members. The implementation of GCI should cover all aspects of the system of higher education institutions. Hence, the GCI Model for Indonesian higher education institutions should cover the GCI policy of higher education institution, academic and non-academic activities, infrastructure and GCI Monitoring and Evaluation.

The implementation of GCI Model for Indonesian higher education institutions may vary from one to another institution depending on its campus size and community number. Yet, it does not imply that the GCI model can only be implemented by big campuses with big number of community members. The GCI model is applicable for all campuses in Indonesia even though the GCI activities may be different. Simple and less cost activities may be appropriate for small campuses. Higher education institutions in Batam whose campuses are much smaller than the ones in Java Island have conducted the GCI activities such as tree planting, recycling, energy saving, paperless system, using eco-enzymes, and so forth. Yet, even if the GCI activities are simple and small, they have a great contribution to environment since all activities can minimize global warming which is suffered by our earth today. In fact, the GCI activities are the concrete roles of campus community members in managing environment as it is required by Law No.32 of 2009. It can be said here that through GCI, campus community members have fully implemented the spirit of 'think globally and act locally'.

\section{REFERENCES}

\section{A. Book}

Amiruddin \& Zainal Asikin, 2004, Pengantar Metode Penelitian Hukum, RajaGrafindo Persada, Jakarta.

Dhyani, S.N, 2004, Fundamentals of Jurisprudence, Central Law Agency, Allahabad.
Hermawan, T.T, 2005, The Role of Universities in Environmental Education in Indonesia, Environmental Education and NGOS In Indonesia, Yayasan Obor Indonesia, Jakarta.

Kusumaatmadja, Mochtar, 1976, Hukum Masyarakat, dan Pembinaan Hukum Na- 
sional, Binacipta, Bandung.

Mertokusumo, Sudikno, 1986, Mengenal Hukum (Suatu Pengantar), Liberty, Yogyakarta.

Pound, Roscoe, 1946, Interpretation of Legal History, Harvard University Press, Cambridge.

Usman, Rahmadi, 2003, Pembaharuan Hukum Lingkungan Nasional, Citra Aditya Bakti, Bandung.

Wignjosoebroto, 2002, Pengantar Metode Penelitian Hukum, RajaGrafindo Persada, Jakarta.

\section{B. Journal Articles}

Houghton, John, "Global Warming", Report on Progress in Physics, Vol. 68, No. 6, June 2005.

Mank, Bradford C., "Standing And Global Warming: Is Injury To All Injury To None?", Environmental Law Journal, Vol. 35, No. 1, 2005.

Sharp, Leith, "Green Campuses: The Road From Little Victories To Systemic Transformation", International Journal of Sustainability in Higher Education, Vol. 3. No. 2002.

\section{Internet Articles}

Anonymous, "The Sustainable Campus", http:// www.sustainablecampus.org/universities. html, accessed on 22 April 2009.

Anonymous, "ISO 9001: Quality Policy atau Kebijakan Mutu", http://iso-9001-forum.blogspot.com/2009/02/iso-9001-quality-policyatau-kebijakan.html, accessed on 22 April 2013.

Harvard University, "Sustainability at Harvard", http://green.harvard.edu/, accessed on 22 April 2009.

Fahlevi, Muhammad Riza, "Efek Global Warming Hajar Batam", http://rizafahlevi.blogspot. com/2009/01/efek-global-warming-hajar- batam.html, accessed on 22 April 2009.

Nasution, Arif Zulkifli, "Green Campus", http:// bangazul.blogspot.com/2012/09/green-campus.html, accessed on 22 April 2009.

Universitas Indonesia, "Mark of Achievement of Universitas Indonesia", http:// www.ui.ac.id/en/profile/page/ mark-of-achievement, accessed on 22 April 2009.

Website Universitas Indonesia, "Green Campus", http://www.ui.ac.id/en/campus/page/greencampus, accessed on 22 April 2009.

Website Universitas Islam Indonesia, "Perangkat Sistem Penjaminan Mutu UII Yogyakarta", http://ipan.staff.uii.ac.id/2009/02/perangkat-sistem-penjaminan-mutu-uii-yogyakarta/, accessed on 22 April 2013.

\section{Magazine}

Anonymous, "HGCI Growing, Growing, Grown!", Harvard Green Campus Initiative Newsletter 07, Spring, Vol. 10, 2007.

Harvard University, "Harvard Green Campus Initiative Newsletter", Spring, Vol. 5, 2004.

\section{E. Regulation}

Law Number 32 of 2009 on Environmental Protection and Management (State Gazette of the Republic of Indonesia Year 2009 No. 140, Supplement to State Gazette of the Republic of Indonesia No. 5009).

\section{F. Convention}

United Nations Framework Convention on Climate Change, May 9, 1992, S TREATY DOC. NO. 102-38, 1771 U.N.T.S. 107, 31 I.L.M. 849 (1992) (entered into force as law in March 1994). 